\title{
稠密バンドル内の流動特性に関する大規模直接解析
}

\section{A Large-Scale Direct Simulation on Fluid Flow Characteristics in a Tight-Lattice Rod Bundle}

\author{
正 高瀬和之（原研） \\ 正 小瀬裕男（大和システムエンジニア） \\ 正 吉田啓之（原研） \\ 正 叶野琢磨（原研） 正 秋本 \\ (原研)
}

\begin{abstract}
Kazuyuki Takase, Japan Atomic Energy Research Institute, 2-4 Shirakata, Tokai-mura, Ibaraki, 319-1195 Yasuo Ose, Yamato System Engineer, 1-17-1 Wakaba-cho, Hitachi-shi, ibaraki, 317-0063 Hiroyuki Yoshida, Japan Atomic Energy Research Institute, 2-4 Shirakata, Tokai-mura, Ibaraki, 319-1195 Takuma Kano, Japan Atomic Energy Research Institute, 6-9-3 Ueno, Taito-ku, Tokyo, 110-0015 Hajimei Akimoto, Japan Atomic Energy Research Institute, 2-4 Shirakata, Tokai-mura, Ibaraki, 319-1195
\end{abstract}

Key Words: Direct Simulation, Tight-Lattice, Rod Bundle, Two Phase Flow, Large-Scale Analysis

\section{1.はじめに}

原研では、軽水炉の高度利用を目指した低減速軽水炉 ${ }^{(1)}$ の 開発を行つている。低減速軽水炉は、減速材の割合を減らし て中吽子の減速を抑制することで 1.0 以上の高い転換比が期 待できる水冷切炉である。炉心には、直径 $13 \mathrm{~mm}$ 程の燃料 棒が $1 \mathrm{~mm}$ 程度の燃料棒間ギャップ幅で三角ビッチ状に稠密 に配置される。燃料集合休の解析には従束からサブチャンネ ル解析コード(2),(3)が利用されるが、实験結果に基づく構成式 を必要とするため、本破究刘象である $1 \mathrm{~mm}$ 程度の狭险流路 に関する灾験デー夕がない場命には高精度の予测は四難で ある。そこで、本䂨究では二相流直接解析コードを使って、 燃料集合体内の流動特性を数値的に評㑋した。本報は、その 評体結果について報尘する。

\section{2. 数值解析}

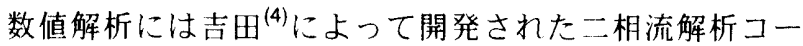
ドを使用した。本コードは界面勾配機能を任し、気液界面形 状を時間及び空間方向に高精度で輸送できる特徽を持つ。

Fig.1 に稠密燃料集合体の解析体系を示す。燃料集合体は、 长さ $1260 \mathrm{~mm}$ 、厚さ $1 \mathrm{~mm}$ 、一边の长さが約 $52 \mathrm{~mm}$ の六角形 断面を付するステンレス製ケーシングと直径 $13 \mathrm{~mm}$ の燃料 棒 37 本から構成される。各然料棒間のギャップは $1.3 \mathrm{~mm}$ ある。冷切材である水は燃料集合体内を下から上に流れる。 燃料集合体内には流れ少向 4 筒所にスペーサが設置される。

解析は、熱の影響がない非加熱等温流条件に刘して、燃料 集合休入山の流速やボイド率を変えて夷施した。気相及び液 相の物吽值は圧」 $7.2 \mathrm{MPa}$ 、飽和温度 $288^{\circ} \mathrm{C}$ における蒸気及 び水の值を使用した。これらの入值は低減速軽水炉の炉心 条件を模擬している。

\section{3. 解析結果}

解析結果の例として、気液界面の分布を Fig.2 に示す。 本図はボイド率 0.5 の等值面を叮視表示したものである。 解析条件は、流路入山で水 $2.4 \mathrm{~m} / \mathrm{s}$ 、蒸気 $6.5 \mathrm{~m} / \mathrm{s}$ 、水之蒸気 の質岸流岸の初期割合は約 7 対 3 で、これは加熱した場合 の然料集合体軸方们中間位置近傍（Fig.1の位置 A）の条件 に相当する。気液界面は、流水力向に対して燃料棒を取り 用むようにほぼ直線的に移行することが少测された。

\section{4. まとめ}

大規模直接シミュレーションによって、椆密燃料集合体内 の流動特性を定革的に予测できる高い見通しが得られた。

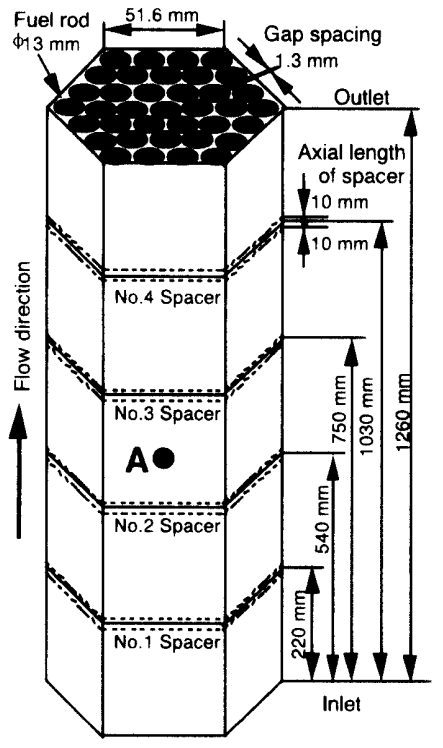

Fig. 1 Analytical geometry of a tight-lattice rod bundle

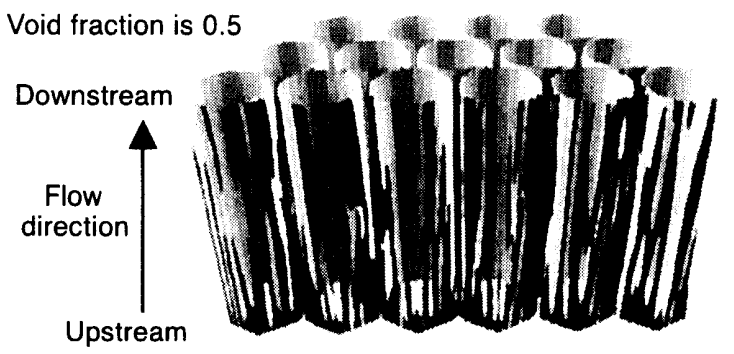

Fig. 2 An interface distribution around fuel rods

\section{引用文献}

(1) Iwamura, T., et al, Proc. of The 13th Pacific Basin Nuclear Conference (PBNC 2002), 1631-1637, China (2002).

(2) Kelly, J.E., Kao, S.P. and Kazimi, M.S., MIT-EL-81-014 (1981).

(3) Thurgood, M.J., NURREG/CR-3046, PNL-4385, 1, R4 (1983).

(4) Yoshida, H., et al, GENES4/ANP2003, Kyoto, Japan (2003). 